\title{
Kemitraan dalam Pengembangan POS PAUD di Kecamatan Kamal Bangkalan
}

\author{
Netty Dyah Kurniasari, Sulaiman, R.M Mochammad Wispandono \\ Program Studi Ilmu Komunikasi Fakultas Ilmu Sosial dan Ilmu Budaya \\ Universitas Trunojoyo Madura \\ E-mail : maretdyah@gmail.com
}

http://dx.doi.org/10.21107/pgd.v4i2.4930

\begin{abstract}
Abstrak
Pos PAUD RA Bakti Telang dan PAUD KB PGRI merupakan PAUD yang berada di Kecamatan Kamal. Semenjak mulai berdiri sampai sekarang terdapat keterbatasan dalam kemampuan proses pembelajaran. Hal ini dikarenakan pengelola/budan PAUD berasal dari ibu rumah tangga dan kader PKK. Kedua mitra mempunyai masakah yang sama khususnya dari sisi penguasaan metode pembelajaran yang kurang menyenangkan bagi anak usia ini. yaitu proses belajar mengajar yang bersifat monoton, tidak (kurang menyenangkan), Kompetensi dan kemampuan tenaga pengajar dalam memahami kurikulum PAUD dan bahan referensi masih terbatas, mengingat usia tenaga pengajar 50 tahun ke atas. Selain itu kemampuan memahami berkembangnya ilmu pengetahuan dan teknologi sangat terbatas, karena jenjang pendidikan tenaga pengajar rata-rata SMA. Proses belajar mengajar yang digunakan terkesan apa adanya. Hal ini bisa dilihat dari tidak adanya modul pembelajaran sehingga menghambat. Metode yang dipakai untuk memecahkan permasalahan adalah melalui kegiatan pelatihan belajar dan mengajar bagi nak PAUD, sehingga target luaran yang dihasilkan adalah sebuah metode pembelajaran yang menyenangkan bagi anak-anak PAUD.
\end{abstract}

Kata Kunci : pengelola POS PAUD, metode pembelajaran, modul, kreatif, inovatif

\section{PENDAHULUAN}

Desa Gili Timur dan Telang merupakan desa yang terletak di Kecamatan Kamal. Desa ini termasuk desa yang tergolong miskin dibandingkan desa lain. Rata-rata pendidikan warga di desa ini adalah SMA dan SMP. Penduduk yang berada di desa ini merupakan campuran antara pendatang dari Surabaya dan penduduk asli Madura (selanjutnya disebut penduduk kampung). Penduduk pendatang dari Jawa (minoritas) memiliki tingkat pendapatan yang lebih tinggi. Sedangkan penduduk kampung rata-rata berpendidikan SMA. Kondisi ini menimbulkan gap (perbedaan) besar khususnya akses pendidikan anak, termasuk akses untuk mengiktui sekolah di Pos PAUD.

Eksistensi Pos PAUD di Desa Gili dan Telang diharapkan menjadi tempat bermain yang menyenangkan dan edukatif pada anak usia dini (golden age) masa emas pertumbuhan anak yang diprioritaskan pada anak semenjak lahir hingga berusia 4 (empat) tahun, sebagaimana amanat ketentuan Pasal 109 Undang-undang Sistem Pendidikan Nasional (selanjutnya disebut UU

Sisdiknas) bahwa salah satu tujuan pendidikan non formal PAUD adalah mengembangkan potensi kecerdasaran spiritual, intelektual, emosional, estetis, kinestetis, dan sosial peserta didik pada masa emas pertumbuhannya dalam lingkungan bermain yang edukatif dan menyenangkan (Zulkifli, 2014).

Pos PAUD yang saat ini dikelola oleh para Kader di lingkungan Desa Gili dan Telang mmeiliki kurang lebih 100 orang anak dengan jumlah Bunda PAUD sebagai pendidik sebanyak 9 orang. Di desa ini penduduknya terdiri dari penduduk pendatang (minoritas, berasal dari Jawa) dan pendudukan kampung Madura. Kondisi kedua warga ini sangat jauh berbeda.Warga pendatang memiliki tingkat pendapatan dan pendidikan yang lebih tinggi (sarjana). Sedangkan penduduk kampung (Madura, mayoritas) hanya mengenyam pendidikan SMP (30\%) dan SMA (70\%). Perbedaan ini membawa implikasi pada kecenderungan menyekolah anaknya.

Bunda PAUD dituntut untuk memiliki kreatifitas. Peluang dan kesempatan memperoleh pelatihan untuk proses pembelajaran dari PAUD sangat terbatas, sementara banyaknya perkembangan dapat membantu para Bunda PUD untuk 'melek informasi' yang akan berpengaruh pada daya kreatifitas pengembangan sarana pembelajaran untuk anak-anak usia PAUD 
(Alfiana, 2015). Perkembangan kognitif menurut Piaget meliputi empat tahap yaitu tahap sensomotorik (0-2 tahun), pada tahap ini pengetahuan diperoleh melalui interaksi fisik baik dengan orang tua maupun benda. Tahap selanjutnya adalah tahap pra-operasional (3-7 tahun), pada tahap ini anak mulai menggunakan simbol-simbol untuk merepresentasikan dunia (lingkungan) secara kognitif. Pada kedua masa ini panca indera berperan sangat besar karena anak akan lebih mudah memahami pengartian dan konsep-konsep melalui menda konkrit, dan disinilah merupakan momen proses pembelajaran terjadi (Alfiana, 2015).

Di sisi lain rata-rata pendidikan para bunda PAUD yang berada di PAUD PGRI dan RA BAKTI sebagai pengajar rata-rata pendidikan SLTA $60 \%$ SLTP 30\% dan Sarjana hanya $10 \%$. Di PAUD PGRI tenaga pengajarnya hanya 3 orang dengan rincian 1 orang saja yang sarjana. Sedangkan di RA BAKTI Telang jumlah pengajarnya sebanyak 6 orang, dengan rincian yang berpendidikan sarjana hanya 3 orang. Ratarata usia para Bunda PAUd di atas 50 tahun sebanyak $40 \%$. Usia 40-50 tahun sebanyak $30 \%$ dan dibawah 40 tahun hanya 30\%. Kondisi tingkat pendidikan dan usia para bunda PAUD yang rata-rata SLTA dan ibu rumah tangga cenderung kurang memhami esensi tujuan pendiidkan PAUD, sehingga proses pembelajara lebih didasarkan pada kondisi mood tidaknya Bunda PAUD.

Eksistensi Pos PAUD di Desa Gili dan Telang diharapkan menjadi tempat bermain yang menyenangkan dan edukatif pada anak usia dini (golden age) masa emas pertumbuhan anak yang diprioritaskan pada anak semenjak lahir hingga berusia 4 tahun, sebagaimana amanat ketentuan Pasal 109 Undang-undang Sistem Pendidikan Nasional (selanjutnya disebut UU Sisdiknas) bahwa salah satu tujuan pendidikan non formal PAUD adalah mengembangkan potensi kecerdasaran spiritual, intelektual, emosional, estetis, kinestetis, dan sosial peserta didik pada masa emas pertumbuhannya dalam lingkungan bermain yang edukatif dan menyenangkan (Zulkifli, 2014).

Berdasarkan pada latar belakang diatas, maka permasalahan yang dihadapi adalah :

a. Tingkat pendidikan pengelola dan tenaga pengajar PAUD terbatas SLTA dan merupakan ibu rumah tangga.

b. Tenaga pengajar memerlukan pemahaman, pelatihan terhadap metode pembelajaran khusus anak usia dini. c. Proses belajar mengajar yang berlangsung selama ini masih terbatas apa adanya, sehingga memerlukan modul yang dapat memberikan arah dan evaluasi proses belajar mengajar baik bagi anak.

Oleh karena itu, kegiatan kemitraan dalam rangka pengembangan POS PAUD di Kecamatan Kamal ini bertujuan untuk :

a. Meningkatkan pemahaman tentang metode pembelajaran PAUD.

b. Memberikan pemahaman tentang teknik dan media komunikasi yang efektif untuk anak PAUD.

c. Meningkatkan kemampuan untuk mencari sarana informasi sebagai peningkatan sarana pembelajaran.

\section{METODE}

Langkah-langkah yang dibutuhkan untuk memecahkan permasalahan mitra adalah sebagai berikut:

a) Pendekatan yang digunakan adalah pendekatan yang digunakan adalah persuasif dan komunikatif (mengingat latar belakang pendidikan dan usia diatas 40 tahun ) serta pendekatan edukatif dengan menekankan bahwa Bunda adalah tenaga pendidik yang nantinya menjadi panutan bagi anak-anak.

b) Penyampaian pelatihan dilakukan secara terstruktur maupun tidak terstruktur, baik indoor maupun outdoor, mengingat para tenaga pengajar membutuhkan waktu yang cukup untuk menyesuaikan suasana dalam acara pelatihan, sehingga target capaian dapat terlampaui.

c) Sarana dan prasarana yang dibutuhkan adalah modul, papan tulis, buku panduan, laptop, $\mathrm{LCD}$, alat peraga maupun poster.

d) Metode pelatihan mennggunakan dua arah (diskusi), kelompok diskusi, pendampingan dan ceramah.

Bentuk partisipasi mitra dalam kegiatan ini adalah mulai dari perumusan masalah, proses pelaksanaan kegiatan serta evaluasi kegiatan. Bentuk partisipasi mitra ini ditunjukkan dengan keikutsertaan dalam pelatihan dan adanya peningkatan kualitas pembelajaran, terutama bertambahnya wawasan dalam hal metode pembelajaran dan melek media internet sehat. Selain memberikan pelatihan berupa model pembelajaran PAUD yang menyenangkan, dilakukan juga penggalian terhadap pola pembelajaran yang dilakukan oleh orang tua siswa.Hal ini penting karena kemajuan dan 
prestasi anak sangat tergantung terhadap pola pembelajaran yang diterapkan di sekolahnya karena sekolah adalah sebagai tempat belajar kedua setelag keluarga. Beberapa hal yang sangat penting terhadap kualitas belajar siswa antara lain metode pembelajaran, kompetensi guru dan sarana (prasarana) yang ada di sekolah.

\section{HASIL DAN PEMBAHASAN}

Hasil penelusuran data menunjukkan beberapa hal. Pertama, desa Gili Timur dan Telang merupakan desa yang terletak di Kecamatan Kamal. Desa ini termasuk desa yang tergolong miskin dibandingkan desa lain. Ratarata pendidikan warga di desa ini adalah SMA dan SMP. Penduduk yang berada di desa ini merupakan campuran antara pendatang dari Surabaya dan penduduk asli Madura. Penduduk pendatang dari Jawa (minoritas) memiliki tingkat pendapatan yang lebih tinggi. Sedangkan penduduk kampung rata-rata berpendidikan SMA. Kondisi ini menimbulkan gap (perbedaan) besar khususnya akses pendidikan anak, termasuk akses untuk mengiktui sekolah di Pos PAUD. Penduduk pendatang lebih memilih menyekolahkan anaknya tidak di PAUD Desa Gili tapi ke desa lain yang dianggap lebih modern baik dari segi metode pembelajarannya, sarana dan prasarana dan kualitas sumber daya manusia. Sementara itu, penduduk kampung yang mempunyai penghasilan minim lebih memilih menyekolahkan anaknya di PAUD PGRI 3 yang berada di desa Gili tersebut. Alasan orang tua wali menyekolahkan anaknya ke sekolah mayoritas karena lokasi sekolah dekat dengan rumah, bukan karena pertimbangan kualitas dan kompetensi guru (sekolah). Ketika ditanya apakah berkeinginan untuk menyekolahkan anaknya ke jenjang lebih tinggi, mayoritas menjawab berkeinginan. Rata-rata orang tua di Kecamatan Kamal menyekolahkan anaknya di PAUD setempat, namun ada juga yang tidak menyekolahkan anaknya ke PAUD. Alasan orang tua tidak menyekolahkan di PAUD karena beberapa hal antara lain orang tua tidak memiliki uang, orang tua tidak memiliki waktu untuk mengantar anak sekolah dan jarak rumah dengan sekolah jauh.

Kedua, Pos PAUD yang saat ini dikelola oleh para Kader di lingkungan Desa Gili dan Telang memiliki kurang lebih 100 (seratus) anak dengan jumlah Bunda PAUD sebagai pendidik sebanyak 9 (Sembilan). Di desa ini pendudukanya terdiri dari penduduk pendatang (minoritas, berasal dari Jawa) dan pendudukan kampung Madura. Kondisi kedua warga ini sangat jauh berbeda.Warga pendatang memiliki tingkat pendapatan dan pendidikan yang lebih tinggi (sarjana). Sedangkan penduduk kampung mayoritas hanya mengenyam pendidikan SMP (30\%) dan SMA (70\%). Perbedaan ini membawa implikadi pada kecenderungan menyekolah anaknya.anak didik. Dengan jumlah tenaga pengajar 3 tenaga pengajar termasuk kepala sekolah. Keberadaan PAUD PGRI 3 ini sangat memprihatinkan baik dari fasilitas, metode pengajaran maupun sumber daya manusianya. Pos PAUD ini tidak memperoleh anggaran dari pemerintah kota Bangkalan. Hingga saat ini tempat PAUD KB PGRI 3 masih mengontrak dengan besar 1 juta per tahun. Pembayaran itu diambil dari infaq wali murid sebesar $\mathrm{Rp}$. 20.000, yang setiap bulannya. Mengingat kondisi perekonomian orang tua anak-anak berasal dari golongan ekonomi menengah ke bawah dengan mata pencaharian sebagai petani.

Ketiga, kedua POS PAUD terdapat keterbatasan dalam kemampuan proses pembelajaran. Hal ini dikarenakan pengelola/budan PAUD berasal dari ibu rumah tangga dan kader PKK. Kedua POS PAUD mempunyai masakah yang sama khususnya dari sisi penguasaan metode pembelajaran yang kurang menyenangkan bagi anak usia ini. yaitu proses belajar mengajar yang bersifat monoton, tidak (kurang menyenangkan), Kompetensi dan kemampuan tenaga pengajar dalam memahami kurikulum PAUD dan bahan referensi masih terbatas, mengingat usia tenaga pengajar 50 tahun ke atas. Selain itu kemampuan memahami berkembangnya ilmu pengetahuan dan teknologi sangat terbatas, karena jenjang pendidikan tenaga pengajar rata-rata SMA. Proses belajar mengajar yang digunakan terkesan apa adanya. Hal ini bias dilihat dari tidak adanya modul pembelajaran sehingga menghambat proses belajar mengajar. Metode pembelajaran yang digunakan tidak (kurang) memperhatikan kebutuhan, perkembangan dan kondisi anak.

Pola pembelajaran yang dilakukan oleh orang tua yang berpendidikan di bawah atau di atas sarjana rata-rata bertipe demokrasi. Hal ini terlihat dari jawaban informan yang mengatakan bahwa orang tua memberikan kesempatan pada anak untuk membicarakan keinginannya. 

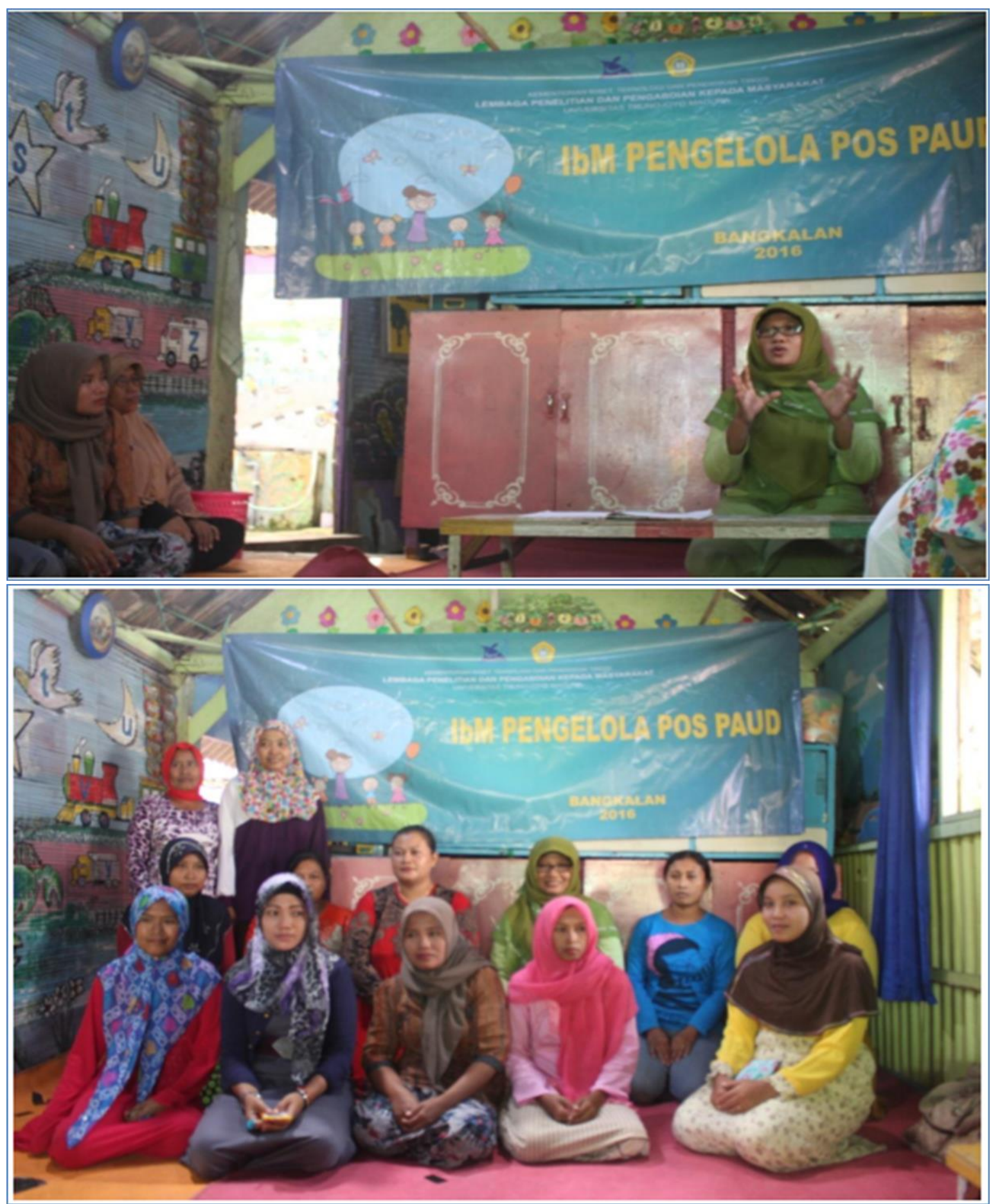

Gambar 1. Pelaksanaan Pendampingan Guru PAUD Kecamatan Kamal Bangkalan

Mereka juga merundingkan segala hal yang terjadi kepada anak dan keluarga. Dari 6 informan orang tua, 4 diantaranya mengatakan bahwa mereka menetapkan pola pengasuhan yang demokrasi, namun ada beberapa hal yang otoriter. Adapun beberapa hal yang otoriter tersebut antara lain: Pertama, anak harus selalu patuh terhadapn peraturan yang dibuat orang tua meskipun anak tidak menyukainya. Kedua, orang tua tidak suka mendengar anak membantah perkataan yang ia bicarakan. Semua keputusan berada di tangan orang tua; dan memarahi anak bahkan memukul adalah hal yang wajar dilakukan orang tua. Dalam hal belajar, mereka mewajibkan dan mengharuskan Mengharuskan anak untuk selalu belajar setiap hari meski anak tidak menginginkannya. Jika anak melakukan kesalahan, orang tua berhak memarahinya bahkan memukul. 


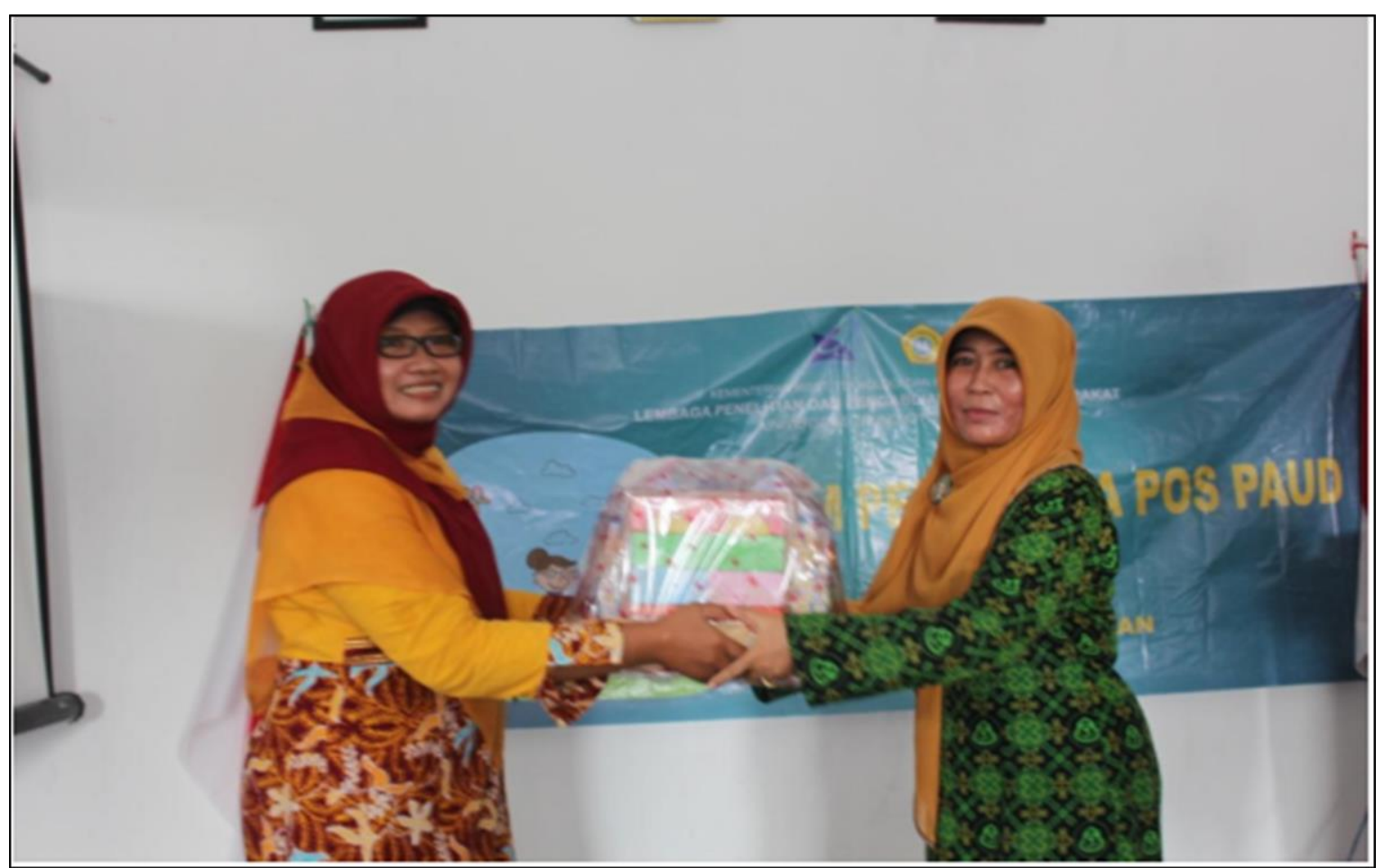

Gambar 2. Pemberian Bantuan Buku dan Media Ajar untuk PAUD

Beberapa hal pola demokrasi yang dilakukan oleh orang tua antara lain memberikan, mendiskusikan segala hal yang terjadi dalam keluarga. Anak diberi kesempatan untuk mengutarakan apa yang ia inginkan.Selain itu orang tua juga menjelaskan pada anak ke tempat yang inginkan, perbuatan baik dan buruk agar anak bisa menentukan mana yang akan ia pilih. Orang tua dalam tipe demokratis ini juga selalu memberikan jadwal harian untuk anak belajar, mereka mengingatkan anak setiap waktu untuk belajar dan selalu bertanya tentang apa yang anak lakukan di sekolah.

Dua informan lain yang pendidikanya di bawah sarjana, memiliki pola pengasuhan yang dominan demokrasi cenderung ke pola permisif. Adapun pola permisif yang dilakukan oleh orang tua berpendidikan di bawah sarjana ini ada beberapa hal antara lain mereka meperbolehkan anak untuk bergaul dengan siapapun, asumsinya sebagai orang tua tidak perlu membatasi pergaulan anak. Selain itu orang tua tipe permisif ini selalu memberikan apa yang diinginkan anak, selalu menuruti kemauan anak meski orang tua tidak menyukainya. Hal tersebut merupakan manifestasi dari cara mereka menunjukkan kasih sayang. Hasil wawancara dengan orang tua wali murid menghasilkan informasi bahwa orang tua beranggapan alasan mereka melakukan itu adalah anak sebenarnya mengerti apa yang ia lakukan, sehingga orang tua tidak perlu atau melarang anak untuk melakukan hal yang ia inginkan. Dengan sendirinya anak akan memahami mana yang baik dan yang buruk tanpa harus diberi tahu orang tua.

Hasil dari kegiatan pengabdian ini didapatkan juga beberapa masukan, tips dan trik terkait proses pembelajaran di PAUD. Beberapa hal tersebut antara lain :

a) Perkembangan teknologi informasi dan komunikasi (TIK) yang sangat besar membawa paradigma baru dalam pendidikan dari berbagai aspek yaitu pembelajaran tradisional ke pembelajaran baru, dari teacher centered ke learner centered dan terjadi perubahan information delivery ke information exchange.

b) Pembelajaran Efektif mempunyai beberapa hal (faktor) antara lain: (1) ekspektasi guru tentang kemampuan peserta didik; (2) keterampilan guru dalam mengelola kelas; (3) jumlah waktu yang digunakan perserta didik untuk menyelesaikan tugas-tugas; (4) kemampuan guru dalam mengambil keputusan pembelajaran; (5) variasi metode pembelajaran.

Dari beberapa diskusi dengan peserta (guru dan orang tua wali), terdapat beberapa kendala untuk menerapkan pembelajaran efektif. Kendala tersebut antara lain:

a) Kurangnya kreativitas dalam pengembangan dan penggunaan media pembelajaran, 
b) Kesejahteraan guru yang belum sesuai dengan harapan

c) Sarana prasarana yang belum memadai.

Beberapa solusi yang didapat dari hasil pengabdian ini antara lain :

a) menjadikan lembaga sebagai tempat belajar.

b) menghargai pengalaman peserta didik sebagai topik pembelajaran.

c) tidak hanya sekolah, rumah dan lingkungan juga dijadikan tempat belajar.

d) guru mengembangkan pembelajaran yang luwes dan memfasilitasi peserta didik memaknai.

\section{KESIMPULAN}

Berdasarkan kegiatan yang dilakukan yang diperoleh permasalahan yang dihadapi dalam dunia pendidikan anak di Madura adalah sumberdaya manusia; kualitas program dan kelembagaan PAUD; minimnya kepedulian orang tuawali anak didik; persepsi masyarakat tentang pentingnya pendidikan; dan minimnya sarana dan prasarana yang ada.Solusi yang dilakukan antara lain pelatihan metode pembelajaran bagi pengajar PAUD, pelatihan pembuatan mainan edukatif. Pola pembelajaran yang digunakan olehorang tua wali murid yang berpendidikan di bawah atau di atas sarjana rata-rata bertipe demokrasi.
Adapun pola permisif yang dilakukan oleh orang tua berpendidikan di bawah sarjana. Beberapa rekomendasi model pembelajaran antara lain pembelajaran langsung, pembelajaran Kooperatif, pembelajaran berbasis masalah. Saran yang dilakukan untuk kegiatan pengabdian ini adalah bisa dilakukan lagi pelatihan khusu kepada orang tua wali murid tentang motivasi dan pola pembelajaran orang tua di rumah.

\section{DAFTAR PUSTAKA}

Agustiawati, I. 2014. Pengaruh Pola Asuh terhadap Prestasi Belajar Siswa pada Mata Pelajaran Akuntansi Kelas XI di SMA Negeri 26 Bandung. Universitas Pendidikan Indonesia.

Alfiana, E.N. 2015. Pola Asuh Orang Tua terhadap Anak dalam Keluarga Pada Bidang Pendidikan di Dusun Pandaan Desa Pandanan Kecamatan Wonosari Klaten. Disertasi. Universitas Negeri Yogyakarta.

Zulkifli, Makhmud, 2014, Pengabdian dan Ipteks untuk Masyarakat : PAUD. Laporan Kegiatan. Universitas Negeri Surabaya. 
Kurniasari, N.D Sulaiman Wispandono, RM Kemitraan dalam Pengembangan POS PAUD 27 